\section{Studia}

\section{z Filologii Polskiej \\ i Stowiańskiej}

DOI: $10.11649 /$ sfps.1801
Studia z Filologii Polskiej i Słowiańskiej, 54

Warszawa 2019

Article No. 1801

Citation:

Фролова, О. Е. (2019). Социальный статус купца в русском языке: Номинативные и характеризующие признаки. Studia $z$ Filologii Polskiej i Słowiańskiej, 54. https://doi.org/10.11649 /sfps.1801

Frolova, O.E. (2019). Sotsial'nyǐ status kuptsa v russkom iazyke: Nominativnye i kharakterizuiushchie priznaki. Studia z Filologii Polskiej i Stowiańskiej, 54. https://doi.org/10.11649/sfps.1801

\author{
Ольга Е. Фролова \\ (Московский государственный университет \\ имени М. В. Ломоносова)
}

\title{
Социальный статус купца в русском языке: номинативные и характеризующие признаки
}

Проблематика языковой картины мира как научного понятия, имеющего интегральную природу, служащего инструментом объяснения мотивов номинации, сочетаемости и метафоризации - давний предмет лингвистических исследований (Апресян, 1995; Бартминьский, 2005; Постовалова, 1988; Сепир, 1993; Серебренников, 1988; Яковлев, 2017). Фиксация различий между разными языковыми картинами мира показывает несовпадение представлений, отраженных в языке, на уровне категоризации (Апресян, 2006; Вежбицка, 2002; Дзюба, 2015; Зализняк, Левонтина, \& Шмелев, 2005; Степанов, 1997). Однако и языковая картина мира одного языка демонстрирует неоднородность и сложное устройство, отражая стереотипные представления о действительности разных слоев общества.

Социальная природа языка проявляет себя весьма разнообразно как в самой системе, так и в речи. С одной стороны, исходя из профессии

This is an Open Access article distributed under the terms of the Creative Commons Attribution 3.0 PL License (creativecommons.org/licenses/by/3.0/pl/), which permits redistribution, commercial and non-commercial, provided that the article is properly cited. (c) The Author(s) 2019.

Publisher: Institute of Slavic Studies, Polish Academy of Sciences

[Wydawca: Instytut Slawistyki Polskiej Akademii Nauk] 
и своего места в общественной иерархии, человек наследует некую лингвистическую микросистему и в соответствии с нею порождает высказывания. Социальный и профессиональный статусы человека формируют и его картину мира: совокупность номинаций объектов и явлений, в том числе, узкоспециальных и неформальных номинаций, а также систему средств оценки. Картина мира, основанная на профессиональной и социальной самоидентификации субъекта, может быть названа социально-корпоративной. Она становится инструментом объяснения мотивов номинаций и связей между языковыми единицами.

С другой стороны, человек, находящийся на определенной социальной ступени, становится предметом наблюдения, обобщения и оценки со стороны представителей других слоев общества. Поэтому единицы, служащие номинациями социальных статусов, мотивируют появление в языке у данных слов коннотаций, порождают переносные оценочные значения (см. Фролова, 2017). И в этом случае номинации социальных статусов включаются уже не в узкосоциальную или профессиональную, а в широко понимаемую языковую картину мира. Таким образом, при построении пространственной модели общей и социально-корпоративной языковых картин мира, корпоративная модель входит в первую по принципу матрешки.

Социальная стратификация стала предметом лингвистического описания, и в частности лексикографической интерпретации (Карасик, 2002; РИС, n.d.). В. И. Карасик пишет:

Социальная стратификация связана с оценкой статусных признаков человека как представителя той или иной социальной группы. Статусная оценка является соотносительной: оцениваются а) статус в системе социальной стратификации, т. е., стратификация в целом (стратификационная оценка), б) статусная позиция вышестоящего, нижестоящего и равного человека (дистанционная оценка), в) соответствие человека статусной норме (ролевая оценка). Стратификационная оценка относится к справедливости и рациональности общественного устройства в целом, дистанционная оценка распространяется на собственный статус субъекта оценки и соотносимые с этим статусом позиции других людей, ролевая оценка связана с вариативностью статусной реализации, т.е. с допустимыми отклонениями от статусного прототипа (Карасик, 2002, с. 70).

Исследователь справедливо отмечает сложность и «многослойность» социальной стратификации и ее отражения в языке. Однако не 
всегда возможно выявить точку зрения и положение на общественной лестнице субъекта оценки, когда предметом оценки становится социальный статус. Исследователь пишет о соответствии прототипу, но не о формировании оценки, инструментом которой становится номинация социального статуса.

Социальные статусы людей в русском языке, заданы сословной системой, формируются ею и организованы иерархически. «Обыкновенно термином „сословие“ обозначают отдельную группу подданных, своим юридическим положением каким-либо определенным образом отличающихся от остального населения, причем отличия эти передаются по наследству. [...] Реформы Екатерины II создали четыре „главных рода людей“: дворян, духовенство, городских обывателей и сельских обывателей» (Лазаревский, 1890-1907). В российском обществе до 1917 г. данная иерархия создана сословным принципом, который был юридически и экономически обоснован, поскольку сословия в зависимости от выплат налогов делились на податные и неподатные.

Поскольку формирование коннотаций и переносных значений представляет собой процесс, при анализе данных явлений исследователь вынужден обращаться к диахронному материалу. На характер оценки влияет синхронная или ретроспективная точка зрения.

Мы намереваемся рассмотреть формирование коннотаций и переносных значений у существительного купеи. Данное слово входит в лексико-семантическую группу социальных статусов: аристократ, армия, барин, боярин, боярство, буржуа, буржуазия, буржуй, вельможа, военный, двор, дворянин, дворянство, духовенство, дьяк, гильдия, император, интеллигент, казак, казачество, командир, крепостной, крепость, крестьянин, кулак, купеи, купечество, лавочник, лакей, люмпен, мещанин, мещанство, монах, нищии, обыватель, опричник, обицер, патриарх, помещик, поп, придворный, приказчик, пролетарий, рабочий, ремесленник, свет, священник, солдат, солдафон, староста, управляющий, холоп, царь, чернь, чиновник, чиновничество.

Купцы представляли собой податное сословие, отличавшееся от дворян и бояр более низким местом в социальной иерархии, характером деятельности, а также образованием и воспитанием.

В качестве материала мы использовали Национальный корпус русского языка и лексикографические источники. Выбор единицы поиска был обусловлен желанием избежать «информационного шума». Мы избрали 
не многозначное существительное купеи, которое способно занимать позицию как таксономического, так и характеризующего предиката, а отыменное прилагательное купеческий. Личные существительные купеи, и купчиха использовались как единицы поиска только для выявления гендерной составляющей стереотипа.

Мы стремимся различать денотативное употребление прилагательного, когда конструкция описывает предмет, явление или ситуацию, относящуюся к роду деятельности представителя социальной страты, и коннотативное употребление, когда словосочетание выступает как оценочное, а объект оценки не обязательно принадлежит к тому же социальному слою. Однако граница между денотативным и коннотативным употреблением не всегда определяется четко. Анализируя сочетаемость в атрибутивных конструкциях, мы хотим выявить частотные конструкции прилагательное + существительное в номинативном, или денотативном, употреблении, а также обнаружить случаи, когда в словосочетании в качестве определяемого слова выступает абстрактное существительное, называющее признак.

Чтобы проследить возникновение коннотаций и, возможно, переносного значения, мы последовательно задали несколько подкорпусов, отражающих развитие права и экономики России: а) 1700-1800, б) 1801-1861, в) 1862-1917, г) 1918-1991, д) 1992-2018. Три первых подкорпуса показывают употребление прилагательного в актуальных контекстах. В период XVIII - начала XX в. купечество было российской буржуазией. Два последних отражают ретроспективный взгляд на российское общество. Кроме того, подкорпус 1918-1992 демонстрирует деактуализацию сем, связанных с финансами, торговлей и промышленностью.

Условия поиска таковы: задается прилагательное, сначала выявляются наиболее частотные конструкции номинативного и оценочного плана. Затем, прослеживая функционирование прилагательного по подкорпусам, мы стремимся выявить сочетаемость и обнаружить динамику предмета оценки. Для описания визуально воспринимаемого гендерного образа представителей интересующего нас социального статуса мы прибегли к поиску по нескольким ресурсам.

Вначале обратимся к лексикографическим источникам. Слово купеи, русское и мотивировано занятиями торговлей. Заимствованный термин буржуазия и личное существительное буржуа появляются в русском языке позже и первоначально встречаются в текстах, посвященных Франции, 
применительно же к российской действительности НКРЯ отмечает их в середине XIX в. БАС указывает на то, что слово купеи, входит в Mameриалы для словаря древнерусского языка по письменным памятникам И. И. Срезневского (БАС, 1950-1965, т. 5, с. 1845), а буржуазия - в Настольный словарь для справок по всем отраслям знания Ф. Г. Толля 1868 г. (БАС, 1950-1965, т. 1, с. 697).

Словарь Академии Российской... дает толкование и переносное значение:

куnец - 1. Тот, который по объявлении известного числа денег, будучи вписан в одну которую-нибудь из трех гильдий, пользуется известными правами в торговле [...] 2. Тот, кто покупает что-либо. На этот товар нет купцов (САР-2, 1806-1822, т. 3, сс. 484-485).

Большой толковый словарь начала ХХІ в. у слова купеи, описывает два значения, касающиеся лиц, занимающихся торговлей от своего имени в Европе и России, а также принадлежащих купечеству. В качестве переносных значений приведены следующие: «3. Разг. Покупатель. [...] | Трад.-нар. О женихе в обряде сватовства. 4. Разг. У моряков: торговое судно» (БТС, 2002, с. 480). Согласно словарю начала XXI в., у личного существительного переносное характеризующее значение не представлено. САР-2 описывает прилагательное купеческий как притяжательное и относительное: «1. Принадлежащий купцам. Купеческий дом. 2. Состоянию купцов свойственный, относительный. Купеческие права, Купеческие извороты» (САР-2, 1806-1822, т. 3, с. 485). САР-2 также приводит еще одно прилагательное, вышедшее из употребления купечественный - «торговый» (САР-2, 1806-1822, т. 3, с. 485). У В. И. Даля сходное толкование: «торговец, посадский, негоциант, торгующий чем-либо; | покупатель» (Даль, 1978-1980, т. 2, с. 219). Современный словарь отмечает оценочное, негативно маркированное значение, только у прилагательного.

Купеческий - 1. к Купец (1 зн.) и Купечество. Купеческое сословие. Купеческие гильдии. Купеческое слово (закреплявшее торговую сделку без письменного документа). 2. Свойственный быту, нравам купцов; торгашеский. Купеческий размах. Купеческая роскошь (безвкусная, аляповатая). Купеческие привычки, замашки (показное расточительство) (БТС, 2002, с. 480).

Слово купечественныц, описанное в САР-2, в БТС не включено и в НКРЯ не встречается.

Теперь обратимся к НКРЯ. У прилагательного купеческий в общем корпусе НКРЯ без временных ограничений обнаруживаются 1675 
документов и 4013 вхождений. При этом выделяются несколько пиков частотности со следующими существительными: быm, дело, дом, дочь, жена, род, семья, слово, сын, сынок, лавка. Далее поиск велся с интервалом 1-3 слова между прилагательным и определяемым существительным.

Характер употребления показан в таблице 1. В столбцах отражены: количество употреблений в общем корпусе без выделения временных границ и употребление по подкорпусам. Порядок строк организован по частотности в общем корпусе - от наиболее к менее частотным.

Таблица 1.

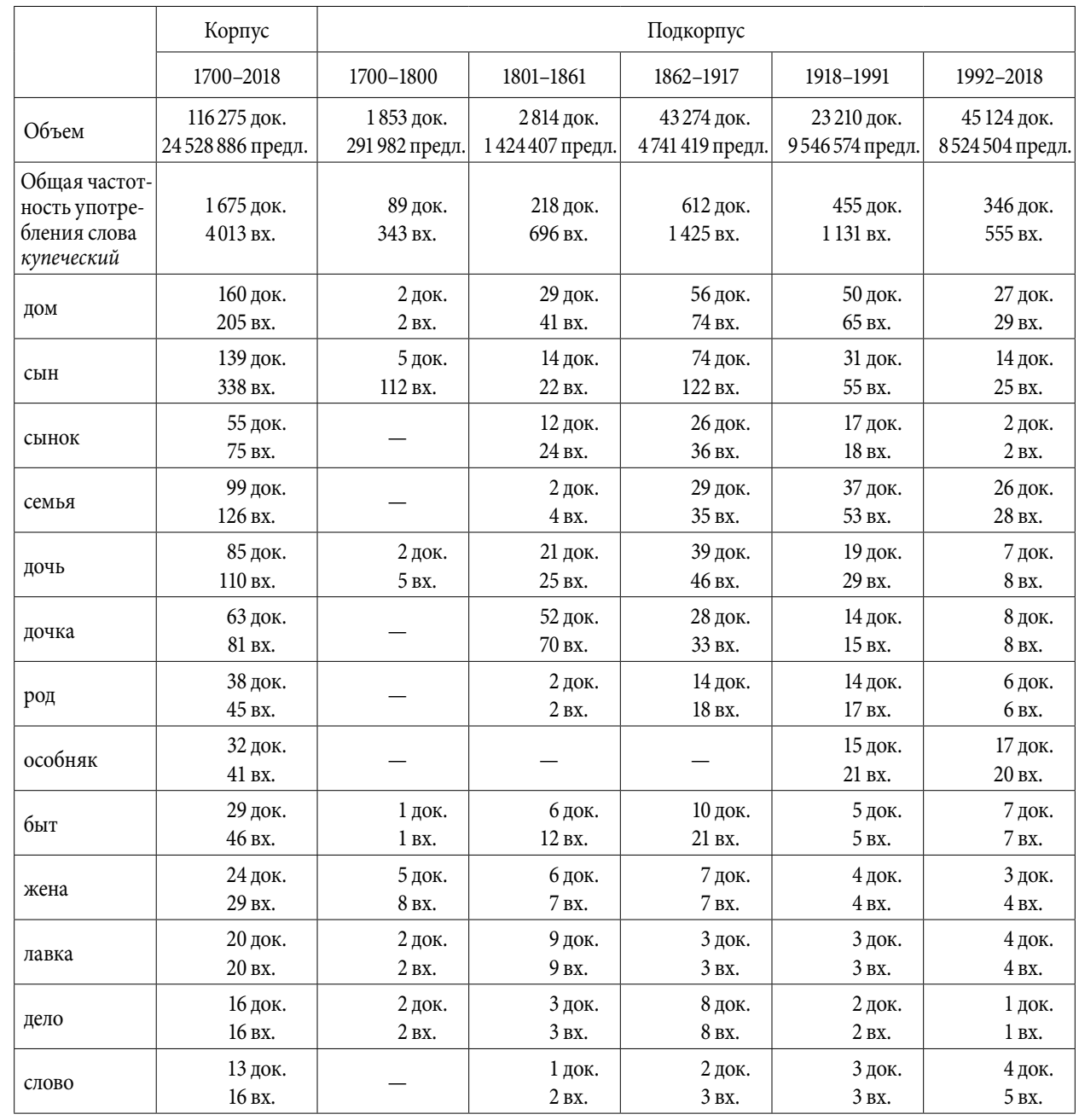


Таблица 1 показывает денотативное употребление. Несовпадение общего количества употреблений и составляющих по подкорпусам объясняется неточностью датировки документа, которая перекрывает заданные временные границы подкорпусов. Значимые по частотности позиции занимают существительные, входящие в тематическую группу семья: дом, сын, сынок, семья, дочь, дочка, род. Это, с нашей точки зрения, свидетельствует о таком устройстве корпоративного начала в торговле и предпринимательстве, которое реализовывалось в границах рода и семьи. САР-2 у слова дом отмечает переносное значение: «в виде имени собирательного означает всех людей к одному семейству принадлежащих» (САР-2, 1806-1822, т. 2, c. 172). Это значение описывает и Словарь 1847 г. (СЦСРЯ, 1847, т. 1, с. 350), и В.И. Даль в несколько иной формулировке «семейство, семья, хозяева с домочадцами | род, поколение, говоря о владетельных или высоких особах» (Даль, 1978-1980, т. 1, с. 466). Из личных существительных лидируют слова сын и сынок, что может быть объяснено наследованием по мужской линии. Из неличных существительных в денотативном употреблении обнаруживают достаточно высокую частотность слова дом (в прямом значении), лавка, дело, слово в значении 'неписаный договор' (см. выше толкование в БТС, 2002, с. 480), а также особняк.

Самое старое употребление слова дом в значении 'семья' в НКРЯ датировано первой четвертью XIX в. В конце XVIII в. НКРЯ фиксирует то же существительное в значении 'жилище' (см. примеры 1,2 ).

(1) [...] пріпьхали на Чистой прудъ, гдю остановясь подль одного купеческаго дому [М. Комаров. Исторія Ваньки Каина со всьми его сысками, розысками, и сумазбродною свадьбою (1779)] (НКРЯ, n.d.).

(2) Мы приищем ему порядочную невесту из купеческого дома [В. Т. Нарежный. Российский Жилблаз, или Похождения князя Гаврилы Симоновича Чистякова (1814)] (НКРЯ, n.d.).

Несмотря на то, что у существительного особняк уже СЦСРЯ отмечает значение «отдельное, не совместное с соседями владение» (СЦСРЯ, 1847, т. 3 , с. 86), в НКРЯ словосочетание купеческий особняк встречается лишь в позднем подкорпусе, когда номинативное употребление становится ретроспективным.

(3) После обеда минут 20 посидели мы в условно-пустом вестибюле Госиздата (в затейном богатом купеческом особняке со всякими архитектурными декоративными причудами) [О. А. Бессарабова. Дневник (1923)] (НКРЯ, n.d.). 
Коннотативные употребления значительно уступают денотативным и могут быть разделены на три группы. Первую мы назовем метагруппой, поскольку единицы, вошедшие в нее, представляют поведение купца как надындивидуальное, групповое, типичное; вторая группа является оценочной и формирует амбивалентный облик купца; третья группа описывает визуальный облик человека, имеющего интересующий нас социальный статус.

В метагруппу вошли следующие единицы: замашка (6 документов, 6 вхождений), манера (6 документов, 6 вхождений), характер (5 документов, 5 вхождений), стиль (3 документа, 3 вхождения), лад (1 документ, 1 вхождение).

Таблица 2.

\begin{tabular}{|c|c|c|c|c|c|}
\hline & \multicolumn{5}{|c|}{ Подкорпус } \\
\hline & $1700-1800$ & 1801-1861 & $1862-1917$ & 1918-1991 & $1992-2018$ \\
\hline Объем & $\begin{array}{c}1853 \text { док. } \\
291982 \text { предл. }\end{array}$ & $\begin{array}{c}2814 \text { док. } \\
1424407 \text { предл. }\end{array}$ & $\begin{array}{c}43274 \text { док. } \\
4741419 \text { предл. }\end{array}$ & $\begin{array}{c}23210 \text { док. } \\
9546574 \text { предл. }\end{array}$ & $\begin{array}{c}45124 \text { док. } \\
8524504 \text { предл. }\end{array}$ \\
\hline \multicolumn{6}{|l|}{$\begin{array}{l}\text { Употребление } \\
\text { прилагатель- } \\
\text { ного купече- } \\
\text { ский }\end{array}$} \\
\hline замашка & - & - & - & $\begin{array}{l}2 \text { док. } \\
2 \text { вх. }\end{array}$ & $\begin{array}{l}4 \text { док. } \\
4 \text { вх. }\end{array}$ \\
\hline манера & - & $\begin{array}{l}1 \text { док. } \\
1 \text { вх. }\end{array}$ & $\begin{array}{l}3 \text { док. } \\
3 \text { вх. }\end{array}$ & $\begin{array}{l}1 \text { док. } \\
1 \text { вх. }\end{array}$ & $\begin{array}{l}1 \text { док. } \\
1 \text { вх. }\end{array}$ \\
\hline характер & - & - & $\begin{array}{l}3 \text { док. } \\
3 \text { вх. }\end{array}$ & $\begin{array}{l}1 \text { док. } \\
1 \text { вх. }\end{array}$ & $\begin{array}{l}1 \text { док. } \\
1 \text { вх. }\end{array}$ \\
\hline стиль & - & - & - & $\begin{array}{l}1 \text { док. } \\
1 \text { вх. }\end{array}$ & $\begin{array}{l}2 \text { док. } \\
2 \text { вх. }\end{array}$ \\
\hline лад & - & - & $\begin{array}{l}1 \text { док. } \\
1 \text { вх. }\end{array}$ & - & - \\
\hline
\end{tabular}

Показательно, что не всегда атрибутивное словосочетание описывает человека.

(4) Да и весь город к тому времени из помещичвего стал на деловой купеческий лад: конторы пошли, банки, склады [П. Д. Боборыкин. «Поумнел» (1890)] (НКРЯ, n.d.).

В примере 4 купеческий стиль определяет облик города.

(5) Застройщики чутко оценили эту ситуачию и предлагают квартиры, которые можно назвать пентхаусами усадебного типа. То есть квар- 
тира может располагаться, предположим, на втором этаже. Но она сделана в привязке к купеческо-дворянскому стилю [Высший класс (2004) // «Мир \& Дом. City», 2004.05.15] (НКРЯ, n.d.).

Пример 5 демонстрирует два явления: семантический перенос и стратификационную контаминацию, поскольку автор соединяет в одном определении нетождественные социальные статусы: аристократический и предпринимательски-торговый.

Значение слова манера, согласно словарю: «1. Образ или способ действия \| Обыкновение, привычка [...] 2. Способ держать себя, внешние формы поведения» (БТС, 2002, с. 519). Данное метаслово можно признать универсальным.

(6) На крыльце появился с довольной ульбкой на желтом, худом лище Власдлинный и тощий, в чесанках и калошах, в черном жилете и синей сатиновой рубахе, на купеческий манер выпущенной из-под жилета. [Г. М. Марков. Строговы. Кн. 1 (1936-1948)] (НКРЯ, n.d.).

(7) Такая психология у нас сбормировалась давным-давно - от бедности, от нищенства. Но это не полное объяснение того, что произошло. Оно было бы полным, если бы люди, которых вы назвали миллиардерами, [...] не бравировали своим богатством в традиционной русской купеиеской манере, не выставляли его напоказ [Александр Яковлев. У нас был фашизм почище гитлеровского (2001)] (НКРЯ, n.d.).

Пример 7 демонстрирует перенос поведенческой характеристики человека на более позднюю историческую эпоху.

Словосочетания купеческий характер, манера, манеры отмечены в подкорпусах, когда такие употребления были актуальными, но встречаются и в советскую, и постсоветскую эпоху, когда социальная структура была уже иной. Существительные замашка и стиль отмечены только для периода 1917-2018 гг. В найденных нами примерах из НКРЯ слово замашка употребляется только переносно.

Оценочную группу сформировали существительные: размах (6 документов, 7 вхождений), вкус (6 документов, 6 вхождений), прихоть (1 документ, 3 вхождения), шик (2 документа, 2 вхождения), роскошь (1 документ, 3 вхождения), самодурство (1 документ, 3 вхождения), изворот (1 документ, 1 вхождение), щедрость (1 документ, 1 вхождение), фатовство (1 документ, 1 вхождение), разгул (1 документ, 1 вхождение), расточительность (1 документ, 1 вхождение), спесь (1 документ, 1 вхождение). 
Таблица 3.

\begin{tabular}{|c|c|c|c|c|c|}
\hline & \multicolumn{5}{|c|}{ Подкорпус } \\
\hline & $1700-1800$ & $1801-1861$ & $1862-1917$ & 1918-1991 & 1992-2018 \\
\hline Объем & $\begin{array}{c}1853 \text { док. } \\
291982 \text { предл. }\end{array}$ & $\begin{array}{c}2814 \text { док. } \\
1424407 \text { предл. }\end{array}$ & $\begin{array}{c}43274 \text { док. } \\
4741419 \text { предл. } \\
\end{array}$ & $\begin{array}{c}23210 \text { док. } \\
9546574 \text { предл. }\end{array}$ & $\begin{array}{c}45124 \text { док. } \\
8524504 \text { предл. }\end{array}$ \\
\hline $\begin{array}{l}\text { Употребление } \\
\text { прилагатель- } \\
\text { ного купече- } \\
\text { ский }\end{array}$ & & & & & \\
\hline размах & - & - & - & $\begin{array}{l}2 \text { док. } \\
3 \text { вх. }\end{array}$ & $\begin{array}{l}4 \text { док. } \\
4 \text { вх. }\end{array}$ \\
\hline вкус & - & $\begin{array}{l}1 \text { док. } \\
1 \text { вх. }\end{array}$ & - & $\begin{array}{l}3 \text { док. } \\
3 \text { вх. }\end{array}$ & $\begin{array}{l}2 \text { док. } \\
2 \text { вх. }\end{array}$ \\
\hline прихоть & - & - & $\begin{array}{l}1 \text { док. } \\
1 \text { вх. }\end{array}$ & - & - \\
\hline шик & - & - & - & $\begin{array}{l}1 \text { док. } \\
1 \text { вх. }\end{array}$ & $\begin{array}{l}1 \text { док. } \\
1 \text { вх. }\end{array}$ \\
\hline роскошь & - & - & $\begin{array}{l}1 \text { док. } \\
1 \text { вх. }\end{array}$ & $\begin{array}{l}1 \text { док. } \\
1 \text { вх. }\end{array}$ & $\begin{array}{l}1 \text { док. } \\
1 \text { вх. }\end{array}$ \\
\hline самодурство & - & - & $\begin{array}{l}2 \text { док. } \\
2 \text { вх. }\end{array}$ & - & - \\
\hline изворот & $\begin{array}{l}1 \text { док. } \\
1 \text { вх. }\end{array}$ & - & - & - & - \\
\hline щедрость & - & $\begin{array}{l}1 \text { док. } \\
1 \text { вх. }\end{array}$ & - & - & - \\
\hline фатовство & - & - & $\begin{array}{l}1 \text { док. } \\
1 \text { вх. }\end{array}$ & - & - \\
\hline разгул & - & - & $\begin{array}{l}1 \text { док. } \\
1 \text { вх. }\end{array}$ & - & - \\
\hline $\begin{array}{l}\text { расточитель- } \\
\text { ность }\end{array}$ & - & - & - & - & $\begin{array}{l}1 \text { док. } \\
1 \text { вх. }\end{array}$ \\
\hline спесь & - & - & $\begin{array}{l}1 \text { док. } \\
1 \text { вх. }\end{array}$ & - & - \\
\hline
\end{tabular}

Определяемые существительные объединяются, с одной стороны, темой 'богатство' (изворот, иик, роскошь, расточительность, щедрость), а с другой, - семами 'отсутствие контроля и ограничений', 'следование своим желаниям', 'демонстративность' (самодурство, батовство, разгул, спесь, размах, прихоть), с третьей стороны - эстетической оценкой (вкус).

Существительное изворот САР-2 определяет как «изыскание средств по случаю затруднения в платеже кому денег» (САР-2, 1806-1822, т. 2, с. 984). Хотя в подкорпусе 1700-1800 встречается словосочетание политический 
uзворот, большинство конструкций с этим существительным связано с деньгами. В примере 8 речь идет о хитрости купцов в финансовых делах.

(8) Граф, приняв от меня рапорты и ведомости, посвятил на ревизию три дни и каждое утро ревизовал присутственные места лично, входил во все подробности, [...] требовал от меня сведений [...] о купеческих изворотах, судоходстве и положении лесов [...] [И. М. Долгоруков. Повесть о рождении моем, происхождении и всей моей жизни, писанная мной самим и начатая в Москве, 1788-го года в августе месяце, на 25-ом году моей жизни / Часть 4 / 1799-1806 (1788-1822)] (НКРЯ, n.d.).

Достаточно часто словосочетание купеческий вкус маркировано отрицательно в разных подкорпусах, его можно интерпретировать как эвфемизм, в котором характеристика сохраняет отрицательную оценку и в актуализованных контекстах (пример 9), и в переносном употреблении (см. примеры 10, 11).

(9) Он был вдов и имел двух взрослых дочерей, дебелых дев, соверменно в купеческом вкусе, то есть толстых, жирных, белых и румяных [Ф. В. Булгарин. Воспоминания (1846-1849)] (НКРЯ, n.d.).

(10) [...] как неразумно у нас используются иветные металлы на различные украшения в угоду обывательским, я бы даже сказал, купеческим вкусам [Л. Бобров. Полимеры и... полумеры // «Юность», 1963] (НКРЯ, n.d.).

(11) [...] она наставляла нас, как не тратить лишних денег, объясняя, что тратить их - это дурной купеческий вкус. [Дуня Смирнова. Natasha Шарымофф, женщина нашего времени (1997) // «Столица», 1997.10.13] (НКРЯ, n.d.).

Пример 12 демонстрирует перенос в употреблении, близком по семантике к существительному размах.

(12) В популярном московском клубе прошла довольно внушительная акиия: 25 часов без перерыва на его маленькой сиене играли самые разные исполнители. [...] Взять вот так и ни с того ни с сего забубенить гигантоманский купеческий нон-стоп в стиле «эй, ухнем!» - на это только «Летчик» способен [Остановите самолет, я слезу. Завершился 25-часовой фестиваль в клубе «Китайский летчик» (2003) // «Известия», 2003.01.27] (HКРЯ, n.d.).

Словосочетания купеческий вкус и роскошь отмечены для актуального и неактуального употребления, т. е. и в XVIII - начале XX в., и в советский, и постсоветский периоды. Как свидетельствуют данные НКРЯ, размах, 
шик и расточительность стали ассоциироваться с социальным статусом купца в 1917-2018 гг. Показательно, что купеческая щедрость отмечена только в первой половине XIX в., когда же структура общества стала иной, возможно, щедрость стала восприниматься как расточительность.

По результатам поиска в визуальную группу вошли лишь два существительных: борода (4 документа, 4 вхождения) и брюхо (4 документа, 5 вхождений).

Таблица 4.

\begin{tabular}{|c|c|c|c|c|c|}
\hline & \multicolumn{5}{|c|}{ Подкорпус } \\
\hline & $1700-1800$ & 1801-1861 & $1862-1917$ & 1918-1991 & $1992-2018$ \\
\hline Объем & $\begin{array}{c}1853 \text { док. } \\
291982 \text { предл. }\end{array}$ & $\begin{array}{c}2814 \text { док. } \\
1424407 \text { предл. }\end{array}$ & $\begin{array}{c}43274 \text { док. } \\
4741419 \text { предл. }\end{array}$ & $\begin{array}{c}23210 \text { док. } \\
9546574 \text { предл. }\end{array}$ & $\begin{array}{c}45124 \text { док. } \\
8524504 \text { предл. }\end{array}$ \\
\hline $\begin{array}{l}\text { Употреб } \\
\text { прилага } \\
\text { тельног } \\
\text { купечес }\end{array}$ & & & & & \\
\hline борода & - & - & $\begin{array}{l}1 \text { док. } \\
1 \text { вх. }\end{array}$ & $\begin{array}{l}3 \text { док. } \\
3 \text { вх. }\end{array}$ & - \\
\hline брюхо & - & $\begin{array}{l}2 \text { док. } \\
2 \text { вх. }\end{array}$ & $\begin{array}{l}1 \text { док. } \\
2 \text { вх. }\end{array}$ & $\begin{array}{l}1 \text { док. } \\
1 \text { вх. }\end{array}$ & - \\
\hline
\end{tabular}

Очевидно, что полученный результат описывает мужчину.

(13) (Дворник, пожалуй, и мастеровой, [...] но его мастерство неподвижно, оно чуждо всяких усовершенствований, оно не требует ничего, кроме сухой, сосредоточенной, крепко сколоченной натуры, грошовой расчетливости да уменья ладить с проезжими, И взамен этого дает оно человеку возможность беззаботно лежать на печи, пить без просыпу и отпускать под старость купеческое брюхо [В. А. Слепцов. Владимирка и Клязьма (1860-1861)] (НКРЯ, n.d.).

(14) Голова его по-солдатски гладко острижена, красноватые щзеки обросли купеческой бородой; на нем крахмаленная рубаха без галстука, синие подтяжки и необыкновенно пестрые брюки [Максим Горький. Жизнь Клима Самгина. Часть 2 (1928)] (НКРЯ, n.d.).

В примере 14 видим «столкновение» визуальных признаков, интерпретируемых различно и не приводящих к однозначной идентификации социального статуса человека: солдатская стрижка и купеческая борода. Кроме того, данное обстоятельство свидетельствует о том, что визуальный признак теряет тесную связь с объектом и воспринимается 
не как характеристика конкретного человека, а визуализация социального статуса.

Поскольку НКРЯ выявил визуальные составляющие образа купца, мы сделали попытку построить целостный образ на их основе. В качестве единицы поиска были заданы словосочетания толстый купеи, и бородатыц̆ куnеи, с интервалом 1-3 единицы. Результат показан в таблице 5.

Таблица 5.

\begin{tabular}{|c|c|c|c|c|c|c|}
\hline & Корпус & \multicolumn{5}{|c|}{ Подкорпус } \\
\hline & $1700-2018$ & $1700-1800$ & $1801-1861$ & $1862-1917$ & 1918-1991 & 1992-2018 \\
\hline Объем & $\begin{array}{c}116275 \text { док. } \\
24528886 \text { предл. }\end{array}$ & $\begin{array}{c}1853 \text { док. } \\
291982 \text { предл. }\end{array}$ & $\begin{array}{c}2814 \text { док. } \\
1424407 \text { предл. }\end{array}$ & $\begin{array}{c}43274 \text { док. } \\
4741419 \text { предл. }\end{array}$ & $\begin{array}{c}23210 \text { док. } \\
9546574 \text { предл. }\end{array}$ & $\begin{array}{c}45124 \text { док. } \\
8524504 \text { предл. }\end{array}$ \\
\hline $\begin{array}{l}\text { Употребле- } \\
\text { ние слово- } \\
\text { сочетания } \\
\text { с купеи }\end{array}$ & & & & & & \\
\hline толстый & $\begin{array}{l}46 \text { док. } \\
65 \text { вх. }\end{array}$ & $\begin{array}{l}1 \text { док. } \\
1 \text { вх. }\end{array}$ & $\begin{array}{l}11 \text { док. } \\
15 \text { вх. }\end{array}$ & $\begin{array}{l}21 \text { док. } \\
35 \text { вх. }\end{array}$ & $\begin{array}{l}14 \text { док. } \\
15 \text { вх. }\end{array}$ & - \\
\hline бородатый & $\begin{array}{l}10 \text { док. } \\
10 \text { вх. }\end{array}$ & - & $\begin{array}{l}2 \text { док. } \\
2 \text { вх. }\end{array}$ & $\begin{array}{l}3 \text { док. } \\
3 \text { вх. }\end{array}$ & $\begin{array}{l}4 \text { док. } \\
4 \text { вх. }\end{array}$ & $\begin{array}{l}1 \text { док. } \\
1 \text { вх. }\end{array}$ \\
\hline
\end{tabular}

Очевидно, что компонент визуального образа брюхо коррелирует с выявленным признаком толстый. Кроме того, выяснилось, что именно эта характеристика является ведущей.

Поскольку визуальный образ носителя социального статуса имеет гендерный характер, мы проверили, какие атрибутивные словосочетания с существительными жена, вдова, дочь, дочка отмечены в НКРЯ. Результат поиска в НКРЯ показал, что в употреблении конструкции «качественное прилагательное + притяжательное прилагательное + существительное жена/ вдова/ дочъ/ дочка» были выделены характеристики толстая, шестипудовая, пухлая.

Далее была проверена сочетаемость слова купчиха (543 документа и 1129 вхождений), а затем частотность конструкций данного личного существительного с прилагательными. Были выявлены словосочетания со следующими прилагательными и причастиями: толстая (20 документов, 20 вхождений), кустодиевская (7 документов, 7 вхождений), семипудовая (6 документов, 10 вхождений), рыхлая (3 документа, 3 вхождения), дебелая (2 документа, 2 вхождения), восъмипудовая (1 документ, 1 вхождение), полная (1 документ, 1 вхождение), пухлая (1 документ, 1 вхождение), 
разжиревшая (1 документ, 1 вхождение), грузная (1 документ, 1 вхождение), дородная (1 документ, 1 вхождение), соблазнительная (1 документ, 1 вхождение), разъевщаяся (1 документ, 1 вхождение).

Для женского образа характеристика толстый оказалась столь же важной, как и для мужского.

Таблица 6.

\begin{tabular}{|c|c|c|c|c|c|c|}
\hline & Корпус & \multicolumn{5}{|c|}{ Подкорпус } \\
\hline & $1700-2018$ & $1700-1800$ & 1801-1861 & 1862-1917 & 1918-1991 & 1992-2018 \\
\hline Объем & $\begin{array}{c}116275 \text { док. } \\
24528886 \text { предл. }\end{array}$ & $\begin{array}{c}1853 \text { док. } \\
291982 \text { предл. }\end{array}$ & $\begin{array}{c}2814 \text { док. } \\
1424407 \text { предл. }\end{array}$ & $\begin{array}{c}43274 \text { док. } \\
4741419 \text { предл. }\end{array}$ & \begin{tabular}{c|}
23210 док. \\
9546574 предл.
\end{tabular} & $\begin{array}{c}45124 \text { док. } \\
8524504 \text { предл. }\end{array}$ \\
\hline \multicolumn{7}{|l|}{$\begin{array}{l}\text { Употребле- } \\
\text { ние слово- } \\
\text { сочетания } \\
\text { с купчиха }\end{array}$} \\
\hline толстая & $\begin{array}{l}20 \text { док. } \\
20 \text { вх. }\end{array}$ & - & $\begin{array}{l}6 \text { док. } \\
6 \text { вх. }\end{array}$ & $\begin{array}{l}9 \text { док. } \\
9 \text { вх. }\end{array}$ & $\begin{array}{l}4 \text { док. } \\
4 \text { вх. }\end{array}$ & $\begin{array}{l}1 \text { док. } \\
1 \text { вх. }\end{array}$ \\
\hline $\begin{array}{l}\text { кустодиев- } \\
\text { ская }\end{array}$ & $\begin{array}{l}7 \text { док. } \\
7 \text { вх. }\end{array}$ & - & - & - & $\begin{array}{l}2 \text { док. } \\
2 \text { вх. }\end{array}$ & $\begin{array}{l}5 \text { док. } \\
5 \text { вх. }\end{array}$ \\
\hline семипудовая & $\begin{array}{l}6 \text { док. } \\
10 \text { вх. }\end{array}$ & - & - & $\begin{array}{l}2 \text { док. } \\
4 \text { вх. }\end{array}$ & $\begin{array}{l}4 \text { док. } \\
6 \text { вх. }\end{array}$ & - \\
\hline рыхлая & $\begin{array}{l}3 \text { док. } \\
3 \text { вх. }\end{array}$ & - & $\begin{array}{l}1 \text { док. } \\
1 \text { вх. }\end{array}$ & $\begin{array}{l}2 \text { док. } \\
2 \text { вх. }\end{array}$ & - & - \\
\hline дебелая & $\begin{array}{l}2 \text { док. } \\
2 \text { вх. }\end{array}$ & - & - & $\begin{array}{l}1 \text { док. } \\
1 \text { вх. }\end{array}$ & - & $\begin{array}{l}1 \text { док. } \\
1 \text { вх. }\end{array}$ \\
\hline $\begin{array}{l}\text { восьмипу- } \\
\text { довая }\end{array}$ & $\begin{array}{l}1 \text { док. } \\
1 \text { вх. }\end{array}$ & - & - & $\begin{array}{l}1 \text { док. } \\
1 \text { вх. }\end{array}$ & - & - \\
\hline
\end{tabular}

Показательна апелляция к образам картин художника Б. М. Кустодиева (1878-1928) Купчиха (1915), Купчиха за чаем (1918), Купчиха перед зеркалом (1920), изображавших купеческую жизнь как некую идиллию. Данная характеристика является исключительно женской. В НКРЯ словосочетание кустодиевский купеи, не представлено.

Вторая характеристика женского визуального образа купчихи богатство костюма и отсутствие вкуса - не получает такого же единообразного способа выражения: разодетая (2 документа, 2 вхождения), разряженная (2 документа, 2 вхождения), расфуфыренная (1 документ, 1 вхождение).

(15) На вид Буластиха показалась ей не столько страшною, сколько вульгарною: огромная толстейшая бабища-купчиха, [...] разряженная безумно: и дорого, и чрезвычайно безвкусно, в камнях всюду, где только 
можно было приткнуть или повесить камушек [А. В. Амфитеатров. Марья Лусьева (1903)] (НКРЯ, n.d.).

В примере 15 представлены обе характеристики.

Пример 16 демонстрирует переносное употребление словосочетания в составе сравнительного оборота.

(16) Постель, напыщенная и вздутая, как толстая купчиха, с двумя пирамидами подушек, китайский фарфор в шкапе за стеклом, картина великого мастера в золотой раме [...] вот что составляло главное украшение знаменитого жилища господ Кульковских [И. И. Лажечников. Ледяной дом (1835)] (НКРЯ).

Подведем итоги. Образ социального статуса в языке оказывается многомерным. Материал НКРЯ позволяет разделить денотативное и коннотативное, оценочное, употребление прилагательного, а также проследить формирование коннотаций. В современном словаре личное существительное лишено оценочного переносного значения, такое значение 'торгашеский' отмечено только у прилагательного. В денотативном употреблении выделяется семантика семьи, важность связей между родственниками в предпринимательском деле. В этом типе употреблений важную роль играют существительные дом и особняк, первое из которых описывает и жилище и семью, а второе употребляется в материале НКРЯ исключительно в ретроспективных контекстах. В коннотативном употреблении выделяется метагруппа, описывающая самые разные стороны поведения купцов и устройства их предприятий, определяющая также облик торговых городов, которые воспринимаются как типичные, присущие всем представителям социального статуса: замашка, манера, стиль, характер. Вторая подгруппа коннотативных употреблений касается богатства, отсутствия контроля и ограничений в поведении, а также невысокого вкуса, которым отмечены поведение, архитектура и обстановка жилища: размах, шик. Кроме того, анализ сочетаемости позволяет выделить небольшую группу единиц, с помощью которых описывается внешность мужчины и женщины, имеющих данный социальный статус: общей социальной характеристикой является телесная полнота, женский образ целостен, образ мужчины-купца представляется «разборным»: для него выделяются детали - борода, брюхо. Образу купчихи присуща манера одеваться демонстративно богато и безвкусно. 


\section{Сокращения}

БАС - Словарь современного русского титературного языка (Чернышев, В. 1950-1965)

БТС - Большой толковый словарь русского языка (Кузнецов, 2002)

НКРЯ - Национальный корпус русского языка, n.d.

РИС - Русский идеографический словарь (Шведова, n.d.)

САР-2 - Словарь Академии Российской, 1806-1822

СЦСРЯ - Словарь иерковно-славянского и русского языка, 1847

\section{Библиография}

\section{Словари}

Даль, В. И. (1978-1980). Толковый словарь живого великорусского языка (Vols. 1-4). Москва: Русский язык.

Кузнецов, С. А. (Ed.). (2002). Большой толковый словарь русского языка [БТС]. Санкт-Петербург: Норинт.

Словарь Академии Российской по азбучному порядку расположенный [CAP-2] (Vols. 1-6). (1806-1822). Санкт-Петербург: Императорская Академия наук.

Словарь иерковно-славянского и русского языка: Составленный вторым отделением Императорской Академии наук [СЦСРЯ] (Vols. 1-4). (1847). Санкт-Петербург: Императорская Академия наук.

Чернышев, В. И. (Еd.). (1950-1965). Словарь современного русского литературного языка [БАC] (Vols. 1-17). Москва, Ленинград: Издательство Академии наук СССР.

Шведова, Н. Ю. (Еd.). (n.d.). Русский идеографический словарь: В 6-ти т. [РИС] [Еlectronic resource]. Retrieved from http://www.slovari.ru/default.aspx? $\mathrm{p}=5485$

\section{Литература}

Апресян, Ю. Д. (1995). Образ человека по данным языка. Вопросы языкознания, 1995(1), 37-67. Апресян, Ю. Д. (Еd.). (2006). Языковая картина мира и системная лексикограбия. Москва: Языки славянских культур.

Бартминьский, Е. (2005). Языковой образ мира: Очерки по этнолингвистике. Москва: Индрик.

Вежбицка, А. (2002). Русские культурные скрипты и их отражение в языке. Русский язык в научном освещении, 2002(2(4)), 6-34.

Дзюба, Е. В. (2015). Лингвокогнитивная категоризация в русском языковом сознании: Монография. Екатеринбург: Урал. гос. пед. ун-т.

Зализняк, А. А., Левонтина, И. Б., \& Шмелев, А. Д. (2005). Ключевые идеи русской языковой картины мира. Москва: Языки славянской культуры. 
Карасик, В. И. (2002). Язык социального статуса. Москва: Гнозис.

Лазаревский, Н. (1890-1907). Сословия. In И. Е. Андреевский, К. К. Арсеньев, \& Ф. Ф. Петрушевский (Eds.), Энииклопедический Словарь Ф. А. Брокгауза и И. А. Ефрона: В 43 m. (Vol.30a) [Electronic resource]. Санкт-Петербург. Retrieved from http://www.vehi.net/brokgauz/

Национальный корпус русского языка [НКРЯ]. (n.d.). Retrieved from http://www.ruscorpora.ru

Постовалова, В. И. (1988). Картина мира в жизнедеятельности человека. In Б. А. Серебренников (Ed.), Роль человеческого фактора в языке: Язык и картина мира (pp. 9-47). Москва: Наука.

Сепир, Э. (1993). Избранные труды по языкознанию и культурологии. Москва: Издательская группа «Прогресс - Универс».

Серебренников, Б. А. (Еd.). (1988). Роль человеческого фактора в языке: Язык и картина мира. Москва: Наука.

Степанов, Ю. С. (1997). Константы: Словарь русской культуры: Опьт исследования. Москва: Школа «Языки русской культуры».

Фролова, О.Е. (2017). О коннотациях слов аристократ, барин, буржуа и их дериватов в русском языке. Известия Уральского федерального университета: Серия 2: Гуманитарные науки, 19(3(166)), 174-190. https://doi.org/10.15826/izv2.2017.19.3.051

Яковлев, А. А. (2017). Языковая картина мира как лингвистическое понятие: Обзор российских публикаций последних лет. Вестник Новосибирского государственного университета: Серия: Лингвистика и межкультурная коммуникация, 15(2), 5-20.

\section{Bibliography (Transliteration)}

\section{Dictionaries}

Chernyshev, V. I. (Ed.). (1950-1965). Slovar' sovremennogo russkogo literaturnogo iazyka [BAS] (Vols. 1-17). Moskva, Leningrad: Izdatel'stvo Akademii nauk SSSR.

Dal', V. I. (1978-1980). Tolkovyi slovar' zhivogo velikorusskogo iazyka (Vols. 1-4). Moskva: Russkiǔ iazyk.

Kuznetsov, S. A. (Ed.). (2002). Bol'shoĭ tolkovyı̌ slovar' russkogo iazyka [BTS]. Sankt-Peterburg: Norint.

Shvedova, N. I. (Ed.). (n.d.). Russkiŭ ideograficheskiŭ slovar': V 6-ti t. [RIS] [Electronic resource]. Retrieved from http://www.slovari.ru/default.aspx?p=5485

Slovar' Akademii Rossǐ̌skoı̆ po azbuchnomu poriadku raspolozhenny [SAR-2] (Vols. 1-6). (1806-1822). Sankt-Peterburg: Imperatorskaia Akademiia nauk.

Slovar' tserkovno-slavianskogo i russkogo iazyka: Sostavlennyı vtorym otdeleniem Imperatorskoı Akademii nauk [STSSRIA] (Vols. 1-4). (1847). Sankt-Peterburg: Imperatorskaia Akademiia nauk.

\section{References}

Apresian, I. D. (1995). Obraz cheloveka po dannym iazyka. Voprosy iazykoznaniia, 1995(1), 37-67. Apresian, I. D. (Ed.). (2006). IAzykovaia kartina mira i sistemnaia leksikografiia. Moskva: IAzyki slavianskikh kul'tur. 
Bartmin'skiŭ, E. (2005). IAzykovoŭ obraz mira: Ocherki po ètnolingvistike. Moskva: Indrik.

Dziuba, E. V. (2015). Lingvokognitivnaia kategorizatsiia v russkom iazykovom soznanii: Monografiia. Ekaterinburg: Ural. gos. ped. un-t.

Frolova, O. E. (2017). O konnotatsiiakh slov aristokrat, barin, burzhua i ikh derivatov v russkom iazyke. Izvestiia Ural'skogo federal'nogo universiteta: Seriia 2: Gumanitarnye nauki, 19(3(166)), 174-190. https://doi.org/10.15826/izv2.2017.19.3.051

IAkovlev, A. A. (2017). IAzykovaia kartina mira kak lingvisticheskoe poniatie: Obzor rossiǔskikh publikatsiĭ poslednikh let. Vestnik Novosibirskogo gosudarstvennogo universiteta: Seriia: Lingvistika i mezhkul'turnaia kommunikatsiia, 15(2), 5-20.

Karasik, V. I. (2002). IAzyk sotsial'nogo statusa. Moskva: Gnozis.

Lazarevskiŭ, N. (1890-1907). Sosloviia. In I. E. Andreevskiŭ, K. K. Arsen'ev, \& F. F. Petrushevskiŭ (Eds.), Entsiklopedicheskiu Slovar' F. A. Brokgauza i I. A. Efrona: V 43 t. (Vol. 30a) [Electronic resource]. Sankt-Peterburg. Retrieved from http://www.vehi.net/brokgauz/

Natsional'nyı̆ korpus russkogo iazyka [NKRIA]. (n.d.). Retrieved from http://www.ruscorpora.ru

Postovalova, V. I. (1988). Kartina mira v zhiznedeiatel'nosti cheloveka. In B. A. Serebrennikov (Ed.), Rol' chelovecheskogo faktora v iazyke: IAzyk i kartina mira (pp. 9-47). Moskva: Nauka.

Sepir, E. (1993). Izbrannye trudy po iazykoznaniiu i kul'turologii. Moskva: Izdatel'skaia gruppa "Progress - Univers".

Serebrennikov, B. A. (Ed.). (1988). Rol' chelovecheskogo faktora v iazyke: IAzyk i kartina mira. Moskva: Nauka.

Stepanov, I. S. (1997). Konstanty: Slovar' russkoı̌ kul'tury: Opyt issledovaniia. Moskva: Shkola "IAzyki russkoĭ kul'tury".

Vezhbitska, A. (2002). Russkie kul'turnye skripty i ikh otrazhenie v iazyke. Russkǐ iazyk $v$ nauchnom osveshchenii, 2002(2(4)), 6-34.

Zalizniak, A. A., Levontina I. B., \& Shmelev, A. D. (2005). Kliuchevye idei russkoŭ iazykovo kartiny mira. Moskva: IAzyki slavianskoĭ kul'tury.

\section{The Social Status of a Merchant in the Russian Language: Nominative and Characterising Features}

\section{Summary}

This article describes connotations of a noun which is a denomination of social status. In the Russian language, the lexico-semantic group "social stratification" is directly related to the hierarchy of legally defined social estates. The study analyses interpretations of meanings of the personal noun kupets 
'merchant' and the adjective kupecheskiu 'merchant' provided in explanatory dictionaries, and examines the connectivity of the adjective in the Russian National Corpus. The results make it possible to distinguish between the denotative and connotative use of the adjectival phrase 'merchant' + noun. In nineteenth-century Russian, the denotative aspect of those attributive word combinations is related to the house and the family, which reflects the features of the corporate structure of merchant enterprise. The connotative group, in turn, is divided into three subgroups: the meta-group, evaluative and visual. The meta-group includes nouns that allow to describe the supra-individual community defined by merchant status: stil' 'style', manera 'manner'. The evaluative subgroup is associated with wealth, absence of control and lack of taste. The visual subgroup of attributive word combinations describes the image of the male merchant using the nouns boroda 'beard' and briukho 'belly'. Identification of the visual image of the female merchant required a change of the search unit in the Russian National Corpus. The combination adjective + adjective 'merchant' + noun zhena 'wife', vdova 'widow', doch' 'daughter', and also phrases with the noun kupchikha 'female merchant' were checked in the Russian National Corpus. In this case, the important characteristics included 'demonstrative wealth of the costume' and 'lack of taste'. The feature 'full body' is not gender-relevant and describes both the male and the female merchant.

\section{Status społeczny kupca w języku rosyjskim. Cechy nominatywne i charakteryzujące}

\section{Streszczenie}

Niniejszy artykuł opisuje konotacje rzeczownika będącego nazwą stanu społecznego. W języku rosyjskim grupa leksykalno-semantyczna „stratyfikacja społeczna" jest bezpośrednio związana z prawnie określoną hierarchią stanów społecznych. Autorka analizuje interpretacje znaczenia rzeczownika osobowego куnеu 'kupiec' i przymiotnika купеческий 'kupiecki' w słownikach języka rosyjskiego oraz łączliwość tego przymiotnika w Narodowym Korpusie Języka 
Rosyjskiego. Uzyskane wyniki pozwalają rozróżnić denotatywne i konotatywne użycie wyrażenia przymiotnikowego „kupiecki + rzeczownik”. W dziewiętnastowiecznym języku rosyjskim denotatywny aspekt tych atrybutywnych połączeń wyrazowych wiąże się z domem i rodziną, co odzwierciedla charakterystykę strukturalną przedsiębiorczości kupieckiej. Użycie konotatywne można natomiast sklasyfikować w trzech podkategoriach: meta, oceniającej i wizualnej. Kategoria meta obejmuje rzeczowniki, które charakteryzują ponadindywidualną wspólnotę definiowaną przez status kupiecki: стиль 'styl', манера 'maniera'. Kategoria oceniająca wiąże się z zamożnością, brakiem kontroli i brakiem smaku. Natomiast kategoria wizualna łączy wygląd kupca-mężczyzny z rzeczownikami бородa ‘broda' i брюхо 'brzuch'. Identyfikacja wyglądu kobiety wymagała zmiany parametrów wyszukiwania w Narodowym Korpusie Języka Rosyjskiego - sprawdzono połączenia przymiotnik + przymiotnik 'kupiecki' + rzeczowniki: жена 'żona', вдова 'wdowa', дочь 'córka' oraz frazy zawierające rzeczownik кynчuха 'kupczyni'. W tym przypadku istotne cechy to między innymi 'demonstracyjnie wystawny ubiór' i 'brak smaku'. Cecha 'pełne ciało' opisuje zarówno kobietę, jak i mężczyznę stanu kupieckiego.

Keywords: denomination of social status; noun; adjective; figurative meaning; connotation; corpus; dictionary; denotative use; connotative use; characterising use

Słowa kluczowe: nazwa stanu społecznego; rzeczownik; przymiotnik; znaczenie przenośne; konotacja; korpus; słownik; użycie denotatywne; użycie konotatywne; użycie charakteryzujące

Olga E. Frolova, Lomonosov Moscow State University, Moscow

ORCID: https://orcid.org/0000-0002-7667-236X

Correspondence: olga_frolova@list.ru

The preparation of this article was financed by the author.

Competing interests: The author is a reviewer of this journal, but did not review any texts in this volume. 